ORIGINAL ARTICLE

\title{
Drug Addiction Pattern and Knowledge on HIV/AIDS Among Male Addicted Undergoing Rehabilitation
}

\author{
*MM Haque ${ }^{1}$, MR Bhuiyan ${ }^{2}$, MR Amin ${ }^{3}$, K Islam ${ }^{4}$, MS Islam $^{5}$ \\ $1 *$ Md Monoarul Haque, Fellow, Dept of Community Nutrition, Faculty of Public Health, \\ Bangladesh University of Health Sciences (BUHS) \\ ${ }^{2}$ Md Rijwan Bhuiyan, MPhil in Public Health, Dept of Health Education \& Health Promotion, Bangladesh \\ University of Health Sciences (BUHS) \\ ${ }^{3}$ Md Ruhul Amin, Assistant Professor, SAIC, Dhaka \\ ${ }^{4}$ Khaleda Islam, Professor, Institute of Nutrition \& Food Science, University of Dhaka \\ ${ }^{5}$ Md Shahinoor Islam, MPhil in Public Health, Bangladesh University of Health Sciences (BUHS)
}

*Corresponding Author

ABSTRACT

Background: The purpose of this study was to assess drug addiction pattern and knowledge on HIV/AIDS among male addicted undergoing rehabilitation.

Methodology: A cross sectional descriptive study was conducted among purposively selected 100 drug addictors in a selected hospital. Pretested semistructured questionnaire was used to collect data by face to face interview.

Result: Mean age of respondents was $34.02+7.12$ years. Result showed that about $39.8 \%$ of the respondents were addicted due to their friends incitement. More than half $(61 \%)$ of the drug addicts were taken both Heroin and Injection (narcotics). About $82 \%$ of the respondents were never sold blood and $18 \%$ were sold their blood due to addiction. More than half $(58 \%)$ of the respondents were taken sex with residential \& commercial sex workers and $27 \%$ were taken sex only with their wives. Only $15 \%$ had no sexual activity. And more than half (57\%) of the respondents did not use condom and $36 \%$ were used condom occasionally during their sexual activity. Only 7\% used condom regularly. Besides study found that more than $97 \%$ of the respondents had knowledge on HIV/AIDS. Only 3\% never heard about HIV/AIDS. Result found that $81.4 \%$ of the respondents had knowledge on the severity of HIV/AIDS disease and $18.6 \%$ did not know. About $89.7 \%$ of the respondents said that they had knowledge on transmission of HIV/AIDS through needle sharing and $10.3 \%$ did not know. Majority of the respondents $75 \%$ had knowledge to prevent HIV/AIDS more than one reason whereas $15.2 \%$ showed other reasons.

Conclusion: Further large scale study should be conducted and the study result should not be generisable.

Key Words: Drug habit, Knowledge on HIV/AIDS

\section{Introduction}

Though Bangladesh is not a drug producing country, but due to its geographical location in between the golden and crescent triangle and passing of the crescent ways through it here the problem of drug abuse has got epidemic form that destroys the productive forces creating special imbalances through narco-terrorism and handicaps the development process ${ }^{1}$. Consequently it has now turned into a wide drug market for the drug traders having national, regional and international roots and during last one and half decades it has flooded over the countries through a compact network of distributive channel $^{1,2}$. This flood appeared so abruptly that the traditional values and inherent social security system even could have any time and scope to develop any preventive measure $^{3,4}$. Drug addiction is now prevalent everywhere AKMMC J 2015; 6(1): 05-09 in Bangladesh; in the house, streets, in the workplace, parks, slums, markets and even in educational institutions both in rural and urban areas. Although there is no precise figure of the drug dependant people, but is estimated around 4.0 million people mostly youths are dependant to some form of drugs, and increased trend among all kinds of people is alarming 5 . Virtually all segments of society are severely affected by this problem. Near about 25 lakh people are drug addicted and among them about 22 thousands are addicted in Dhaka city. In Bangladesh about 80 percent of the drug addicts are adolescents and young men of 15 to 30 years of age ${ }^{6}$. Drug addiction induces immunonutritional deficiency ${ }^{9}$. Use of illicit drugs produces multiple nutrient deficiencies or malnutrition ${ }^{9,10}$, which is the 
most common cause of immunodeficiency ${ }^{11-14}$. Immunocompetence is a sensitive and functional determinant of nutritional status because it is altered even before the onset of clinical symptoms of malnutrition ${ }^{9}$. Illicit drugs are themselves immunosuppressive ${ }^{15-20}$. Use of these drugs undermines appetite ${ }^{21}$, affects food habits, leading drug addicts to crave 'empty-energy', potentially nutrient-deficient foods ${ }^{22}$, and causes micronutrient deficiency ${ }^{10}$. Thus, the use of illicit drugs produces immunonutritional deficiencies, and influences susceptibility to infectious agents, including HIV infection ${ }^{10}$. In addition drug addicts' behavioural risk factors such as needle-sharing, unprotected sex, sex with multiple partners, etc. ${ }^{10,23,24}$ ranks them at the highest risk of HIV infection ${ }^{10,25}$. Basically drug addicts have very limited knowledge about HIV/AIDS infection which will prone them to a vulnerable stage. The purpose of this study to evaluate the drug intake pattern and their knowledge about HIV/AIDS infection.

\section{Methodology}

Study design: This was a cross sectional study

Study population and area: This study was carried out among male drug addicts who were admitted for detoxification and rehabilitation therapy, counseling and motivation at Dhaka ahsania Mission (DAM).

Study sample and sampling method: For the purpose of this study, 100 drug addicts were selected purposively from Dhaka Ahsania Mission (DAM).

Study Period: This study was conducted from March 2006 to December 2006

Tools: A semi structured questionnaire was used to conduct this study. Questionnaire includes sociodemographic conditions, drug intake pattern and knowledge about HIV/AIDS.

Data collection methods: Data was collected by face to face interview from the respondents.

Data analysis: The data were analyzed using SPSS/PC (version 12). The raw data recorded in questionnaire was code first. The coded data were entered in to computer in SPSS program. Finally all required analysis was done by simple cross-tabulation.

\section{Result}

The table 1 showed distribution of the respondents by age. $30 \%$ were in the 26-30 years age group. About $10 \%$ were found in the age group of 20-26 years. $23 \%$ were in the age group of $31-35$ and $21 \%$ were found in 36-40. The overwhelming more than $50 \%$ of the respondents were married and $44 \%$ of them unmarried. Table showed that $35 \%$ of the respondents had passed secondary classes while $19 \%$ were completed primary education. Almost $21 \%$ respondents were found to sign, read and write only. $17 \%$ were illiterate whereas only $8 \%$ respondents had graduation degree and higher secondary certificate examination. $36 \%$ of the respondents had small business. $14 \%$ respondents were Rickshw puller and driver. Whereas only were day laborer. 19\% respondents were found to have job whereas $6 \%$ were jobless. $10 \%$ respondents were found to picking paper and remaining $10 \%$ were involved in other function. Study shows $07 \%$ respondents had no income. $36 \%$ of the respondents were found in $41,00-8,000 /$ - income group and $28 \%$ had income within $4,000 /-$. In case of duration of staying in DAM shows that $61.6 \%$ of the respondents were shown to stay on 1-7 days. $14.1 \%$ were shown to stay form 8-14 days and 22.2 were shown to stay more 1 month. Table shows that $31 \%$ of the respondents got admitted at DAM from care $\mathrm{Bd}$. Whereas $30 \%$ got admitted from those who took Whereas $30 \%$ got admitted from those who took treatment from DAM. 17\% were admitted from their surrounding community person and $9 \%$ admitted from other sources.

Table 1: Socio-economic characteristics of the respondents $(\mathrm{n}=100)$

\begin{tabular}{|c|c|c|c|}
\hline Items & Frequency & Percentage (\%) & Mean \pm SD \\
\hline $20-25$ & 10 & 10.0 & \\
\hline $26-30$ & 30 & 30.0 & \\
\hline $31-35$ & 23 & 23.0 & $34.02+7.12$ \\
\hline $36-40$ & 21 & 21.0 & \\
\hline $41 \&$ above & 16 & 16.0 & \\
\hline \multicolumn{4}{|l|}{ Marital status } \\
\hline Married & 56 & 56.0 & \\
\hline Unmarried & 44 & 44.0 & \\
\hline \multicolumn{4}{|l|}{ Educational level } \\
\hline Illiterate & 17 & 17.0 & \\
\hline Can sign, red, write & 21 & 21.0 & \\
\hline Primary & 19 & 19.0 & \\
\hline Secondary & 35 & 35.0 & \\
\hline 11 Graduate & 08 & 8.0 & \\
\hline \multicolumn{4}{|l|}{ Occupation } \\
\hline Rickshaw Puller and Driver & 14 & 14 & \\
\hline Day labor & 05 & 5.0 & \\
\hline Small business & 36 & 36.0 & \\
\hline Service & 19 & 19.0 & \\
\hline Jobless & 06 & 6.0 & \\
\hline Paper picking & 10 & 10.0 & \\
\hline Others & 10 & 10.0 & \\
\hline \multicolumn{4}{|l|}{ Monthly income } \\
\hline No income & 07 & 7.0 & \\
\hline Up to 4,000 & 28 & 28.0 & \\
\hline $4,000-8,000$ & 36 & 36.0 & \\
\hline $8,000-12,000$ & 18 & 18.0 & \\
\hline$>12,000$ & 11 & 11.0 & \\
\hline \multicolumn{4}{|c|}{ Staying in the Ahasania mission Hospital (days) } \\
\hline $1-7$ days & 61 & 61.0 & \\
\hline $8-14$ days & 14 & 14.0 & \\
\hline $22-28$ days & 2 & 2.0 & \\
\hline 29 and above days & 23 & 23.0 & \\
\hline \multicolumn{4}{|c|}{ Person who helped in taking Rehabilitation } \\
\hline Staff of AMH & 13 & 13.0 & \\
\hline Care of BD & 31 & 31.0 & \\
\hline Community person & 17 & 17.0 & \\
\hline Who took treatment for DAM & 30 & 30.0 & \\
\hline Others & 9 & 9.0 & \\
\hline
\end{tabular}

Table 2 showed that about $39.8 \%$ of the respondents were addicted due to their friends incitement and 
$2 \%$ were addicted due to self curiosity. $1 \%$ were addicted intentionally and carelessness of their family member. $8.2 \%$ were addicted due to their surrounding environment. $24.5 \%$ were addicted during buying drugs for other. 9\% were addicted due to more than one reason whereas 10.2 were for other reasons. In case of age when they first took drug. $58.4 \%$ of the respondents were found in the 13-18 years age group whereas $12.4 \%$ were in the 8-12 years age group. 29\% respondents were found in the 19 and above year's age group. About 38.4\% of the respondents were addicted from 5-8 years whereas $21.2 \%$ were from 1-4 years. $20.2 \%$ were addicted from 9-12 years and $15.2 \%$ were from 1316 years. $5.1 \%$ were addicted from more than 17 years. More than half $(61 \%)$ of the drug addicts were taken both Heroin and Injection. 21\% were taken only Heroin and $18 \%$ were taken injection. About $85 \%$ of the respondents were taken drug 1-3 times. $13 \%$ were taken drug 4-6 times whereas only $2 \%$ were taken drug more than 7 times. More than half $(64 \%)$ of the respondents were expend on drug almost 200 taka daily. 22\% were expend on drug 201-400 taka. $11 \%$ were expending on drug 401600 taka daily. The result obtained in this study showed that per capita per day expenditure on drug is 231.7 taka. And by assuming 25 lacs drug addicted people in Bangladesh then total annual expenditure on drug is 21078,7500000 - (Twenty one thousand seventy eight crore and seventy five lacks) taka. Table 2 also showed that the nature of using drug by the respondents. $26 \%$ of the respondents were shown to share dose but not syringe and $17 \%$ did not share does /syringe. $21 \%$ were showed to share syringe and $16 \%$ of the respondent were shown to share are both dose and syringe. 17\% were respondents found to share syringe in the past but not now and get from CARE. About $82 \%$ of the respondents were never sold blood and $18 \%$ were sold their blood due to addiction. More than half $(58 \%)$ of the respondents were taken sex with residential \& commercial sex workers and $27 \%$ were taken sex only with their wives. Only $15 \%$ had no sexual activity. And more than half $(57 \%)$ of the respondents did not use condom and $36 \%$ were used condom occasionally during their sexual activity. Only 7\% used condom regularly.
MM Haque, MR Bhuiyan, MR Amin et al

Table 2: Distribution of the respondents about drug intake habits before coming DAM $(n=100)$

\begin{tabular}{|c|c|c|}
\hline Way of becoming addicted & Frequency & Percentage \\
\hline Self curiosity & 2 & 2.0 \\
\hline Friend incitement & 39 & 39.0 \\
\hline Intentionally & 1 & 1.0 \\
\hline Carelessness of the family & 1 & 1.0 \\
\hline Environmental & 8 & 8.0 \\
\hline During buying drugs & 5 & 5.0 \\
\hline Emotional & 24 & 24.0 \\
\hline Self curi. \& Emotionally & 9 & 9.0 \\
\hline Others & 11 & 11.0 \\
\hline \multicolumn{3}{|l|}{ Age in first drug addicted } \\
\hline Child hood (8-12) & 12 & 12.0 \\
\hline Teen age (13-18) & 58 & 58.0 \\
\hline $19 \&$ above & 30 & 30.0 \\
\hline \multicolumn{3}{|l|}{ Period of addiction (y ears) } \\
\hline $1-4$ & 21 & 21.0 \\
\hline $5-8$ & 38 & 38.0 \\
\hline $9-12$ & 20 & 20.0 \\
\hline $13-16$ & 15 & 15.0 \\
\hline $17+$ & 6 & 6.0 \\
\hline \multicolumn{3}{|l|}{ Type of drugs } \\
\hline Heroin & 21 & 21.0 \\
\hline Injection & 18 & 18.0 \\
\hline Both & 61 & 61.0 \\
\hline \multicolumn{3}{|l|}{ Frequency of drug intake (daily) } \\
\hline $1-3$ times & 85 & 85.0 \\
\hline 4-6 times & 13 & 13.0 \\
\hline $7 \&$ above & 2 & 2.0 \\
\hline Total expendi ture on drug(Tk) & & \\
\hline Up to 200 & 64 & 64.0 \\
\hline $201-400$ & 22 & 22.0 \\
\hline $401-600$ & 11 & 11.0 \\
\hline$>600$ & 3 & 3.0 \\
\hline \multicolumn{3}{|l|}{ Nature of using drug } \\
\hline Sometime share dose but not syringe & 26 & 26.0 \\
\hline Don't share dose/syringe & 17 & 17.0 \\
\hline Use syringe $2-3$ times by himself & 3 & 3.0 \\
\hline Share syringe & 21 & 21.0 \\
\hline share both & 16 & 16.0 \\
\hline Share syringe in the past but at moment don,t & 8 & 8.0 \\
\hline Get from care & 9 & 9.0 \\
\hline \multicolumn{3}{|l|}{ Selling blood } \\
\hline Yes & 18 & 18.0 \\
\hline № & 82 & 82.0 \\
\hline \multicolumn{3}{|l|}{ Status of sex partners } \\
\hline Wife & 27 & 27.0 \\
\hline Commercial sex worker & 31 & 31.0 \\
\hline
\end{tabular}

Table 3 showed that more than $97 \%$ of the respondents have had knowledge on HIV/AIDS. Only 3\% never heard about HIV/AIDS. In case of knowledge on sources of HIV/AIDS transmission, shows that $14 \%$ of the respondents heard from TV/Radio whereas $13.3 \%$ heard from NGOs. $21.4 \%$ respondents heard from more than one sources and $9.2 \%$ heard from their colleagues. $38.8 \%$ respondents heard from other sources. Result found that $81.4 \%$ of the respondents had knowledge on the severity of HIV/AIDS disease 
and $18.6 \%$ did not know. About $89.7 \%$ of the respondents said that they had knowledge on transmission of HIV/AIDS through needle sharing and $10.3 \%$ did not know. In case of knowledge about the symptoms of HIV/AIDS, study shows that $4.3 \%$ of the respondents had knowledge on chronic coughing whereas $7.4 \%$ had knowledge on weight loss. $4.3 \%$ had knowledge on fever and $27.7 \%$ had no idea on symptom of AIDS. 56.4\% respondents had knowledge's on others. About $88.0 \%$ of the respondents had knowledge on HIV/AIDS transmission by sexual contact with HIV/AIDS attacked person and $12 \%$ did not know. And about $1.1 \%$ respondents had knowledge to avoid sex with HIV/AIDS affected person. $4.3 \%$ were showed to use condom during sexual activities. $3.3 \%$ had knowledge to avoid used syringe. Majority of the respondents $75 \%$ had knowledge to prevent HIV/AIDS more than one reason whereas $15.2 \%$ showed other reasons.

Table 3: Distribution of the respondents about Knowledge on HIV/AIDS $(n=100)$

\begin{tabular}{|c|c|c|}
\hline Heard the term: HIV/AIDS & Frequency & Percentage \\
\hline Yes & 96 & 97.0 \\
\hline No & 3 & 3.0 \\
\hline \multicolumn{3}{|l|}{ Source of information about HIV/AIDS } \\
\hline Colleagues & 9 & 9.2 \\
\hline TV/Radio & 14 & 14.3 \\
\hline Read Books & 3 & 3.1 \\
\hline NGOs & 13 & 13.3 \\
\hline Mors than one so urces & 21 & 21.4 \\
\hline Others & 38 & 38.8 \\
\hline \multicolumn{3}{|c|}{ Knowledge about the severity of HIV/AIDS } \\
\hline Yes & 79 & 81.4 \\
\hline No & 18 & 18.6 \\
\hline \multicolumn{3}{|c|}{ Knowledge of transmission of HIV/AIDS by needle sharing } \\
\hline Yes & 81 & 89.7 \\
\hline No & 10 & 10.0 \\
\hline \multicolumn{3}{|c|}{ Knowledge of transmission of HIV/AIDS by sexual contact } \\
\hline Yes & 81 & 88.0 \\
\hline No & 11 & 12.0 \\
\hline \multicolumn{3}{|c|}{ Knowledge about symptom on AIDS attacks } \\
\hline Chronic coughing & 4 & 4.3 \\
\hline Weight loss & 7 & 7.4 \\
\hline Fever & 4 & 4.3 \\
\hline Don't know & 26 & 27.7 \\
\hline & 53 & 56.4 \\
\hline \multicolumn{3}{|l|}{ Knowledge on prevention of HIV/AIDS } \\
\hline HIV+ & 1 & 1.1 \\
\hline Use condom & 4 & 4.3 \\
\hline Syringe & 3 & 3.3 \\
\hline Condom and Syringe & 26 & 28.3 \\
\hline HIV. Condom and Syringe & 18 & 19.6 \\
\hline More than one reasons & 26 & 28.3 \\
\hline Others & 14 & 15.2 \\
\hline
\end{tabular}

\section{Discussion}

The study findings show that more than one third (39.8\%) respondents become addicted from peer pressure. Which is most common cause of drug addiction? Several studies found that peer influences have been found to be among the strongest predictors of drug use during adolescence 26 . About more than half of the respondents $(58.4 \%)$ started or experienced in drug during their teen age (13-18 years). In developing countries studies found that almost $80 \%$ drug addicted become addict in drug during teen age 6 . In case of taking different forms of drugs, almost majority of the respondents $(61 \%)$ took drug in both Heroin and Injection. In case of sharing dose, about $26 \%$ respondents share their dose to the partners and $21 \%$ share syringe to their partners. Study found that about one third $(31 \%)$ respondents did sex with commercial sex workers. And more than half $(57 \%)$ respondents did not use condom during sexual activities. The study findings are almost similar to the other findings dune in Bangladesh ${ }^{27-30}$.

Majority (97\%) of the respondents have heard the term HIV/AIDS disease where $81.4 \%$ also have knowledge about the severity of this disease. Almost majority $(89.7 \%)$ respondents have knowledge how to transmit HIV/AIDS and almost half have knowledge about how to prevent this disease. One study conducted in alcohol Egypt on drug abusers and found good knowledge about HIV/AIDS ${ }^{31}$.

\section{Conclusion}

The study provided some part of information about knowledge on HIV/AIDS among drug addictors. Further large scale study should be conducted and the study result should not be generisable.

\section{Conflict of interest : None.}

\section{References}

1. Kamal, M, 2006, Drug Abuse in Bangladesh: Responses of Public and Non Public Governance, Available from: http://www.napsipag.org/pdf/MASUDA_KAMAL.pdf

2. Ahmad Aka Firowz, Implication of Drugs in the Workplace in Bangladesh, Role of Employers, Employees \& Unions. Paper presented of the Seminar on mobilizing workplaces to Prevent Drug Abuse in Asia, 18-21 December 2001, Bangkok, Thailand.

3. SAARC Forum (1995): The Role of NGO's in Drug Demand Reduction: Report of the meeting held at Dhaka, Bangladesh, April 1995.

4. Ahmed S.K. 2001, Community intervention team : an approach to drug abuse risk, livelihoods and Communities in Asia, Presented at 12th, International Harm Reduction Conference, 1-5 March 2001, New Delhi, India. 
5. Ahsania mission, Drug Addiction Treatment \& Rehabilitation Centre, Available from: http://www.amic.org.bd/index.php?option = com_content\& view $=$ article $\&$ id $=58 \&$ Itemid $=56$

6. Shazzad MN, Abdal SJ, Majumder MSM, et al. Drug Addiction in Bangladesh and its Effect, Medicine today. 2013. November 02;25:84-89

7. Finnegan LP (1998) Perinatal Morbidity and Mortality in Substance Using Families: Effects and Intervention Strategies, pp. 1-21. Rockville, MD: NIDA, NIH, US Department of Health and Human Services.

8. Johnson A \& Gerstein DR. Initiation of use of alcohol, cocaine, and other substances in US birth cohorts since 1919. American Journal of Public Health 1998;88: 27-33.

9. Varela P, Marcos A, Santacruz I, et al. Human immunodeficiency virus infection and nutritional status in female drug addicts undergoing detoxification: anthropometric and immunologic assessments. American Journal of Clinical Nutrition1997; 66, 504S-508S.

10. Islam $\mathrm{SN}$, Hossain $\mathrm{KJ} \&$ Ahsan $\mathrm{M}$. Original communication: Serum vitamin E, C and A status of the drug addicts undergoing detoxification: influence of drug habit, sexual practice and life style factors. European Journal of Clinical Nutrition 2001; 55, 1022-1027.

11. Beisel WR. Nutrition in paediatric HIV infection: setting the research agenda Nutrition and immune function: Overview. Journal of Nutrition 1996; 126, Suppl., 2611S-2615S.

12. Chandra RK. Nutrition and the immune system: an introduction. American Journal of Clinical Nutrition 1997; 66, 460S-463S.

13. Chandra RK (2001) Introduction and state of the art and science of nutrition and immunology (abstract). In The 17th International Congress of Nutrition, 27-31 August 2001, Vienna, Austria, p. 288 [I Elmadfa and J Konig, editors]. New York and London: Medical and Science Publishers.

14. Hegde HR, Woodman RC \& Sankarn K. Nutrients as modulators of energy in AIDS. Journal of the Association of Physicians of India 1999; 47: 318-325.

15. Brown SM, Stimmel BT \& Taub RN. Immunologic dysfunction in heroin addicts. Archives of Internal Medicine 1974; 134: 1001-1006.

16. Rouveix B. Opiates and immune function: consequence on infectious disease with special reference to AIDS. Therapie 1992; 47: 503-512.

17. Courssons-Reed ME, Dykstra LA \& Lystle DT. Pavlovian conditioning of morphine induced alterations of immune status. Brain Behavior Immunology 1994; 8: 204-217.

18. Carr DJJ \& Serou M. Exogenous and endogenous opioids as biological response modifiers. Immunopharmacology 1995; 31: 59-71.

19. Thomas PT, Bhargana HN \& House RV. Immunomodulatory effects of in vitro exposure to morphine and its metabolites. Pharmacology 1995; 50: 51-62.
20. Miyagi AU, Chuang T, Lam KM, et al. Opioids suppress chemokine-mediated migration of monkey neutrophils and monocytes - an instant response. Immunopharmacology 2000;47: 53-62.

21. Vasko ME (1992) Drug abuse and dependence. In Goth's Medical Pharmacology, 13th ed. pp. 336-353 [WO Clerk, DE Brater and AR Johnson, editors]. St. Louis, USA: Mosby Year Book.

22. Mohs ME, Watson RR \& Leonard-Green T. Nutritional effects of marijuana, heroin, cocaine and nicotine. Journal of the American Dietetic Association 1990; 90: 1261-1267.

23. Bluthenthal R, Kral A, Gee L, et al. The effect of syringe exchange use on high risk IDUs: a cohort study. AIDS 14, 605-611.

24. Booth R, Kwiatkowski C, Chitwood D. Sex-related HIV risk behaviors: differential risk among IDUs, crack smokers, and IDUs who smoke crack. Drug and Alcohol Dependence 2000; 58: 219-226.

25. Choi KH, Xiwen Z, Shuquan Q, et al. HIV risk among patients attending sexually transmitted diseases clinic in China. AIDS and Behavior 2000; 4: 111-119.

26. Lamsal, p, 2008, Peer pressure leading cause of drug addiction, Available from: http://www.gorkhapatra.org.np/detail.php?article_id=31 $825 \&$ cat_id $=4$

27. Islam RN, Noor-E-Tabassum, Shamsuzzaman AM, et al. A Case Study of Drug Abuse, Dinajpur Med Col J 2013 Jan; 6(1), Available from: http://www.dinajmc.org/ journal/djmcj_v6_i1_pdf/24_djmcj_case_120_rifat_drug _ abuse.pdf

28. Akhter, J, 2012, Prevalence of Substance Abuse among Female Residential Students of Dhaka University, ASA University Review, Vol. 6 No. 1, January-June, 2012, Available from: http:// www.asaub.edu.bd/data/ asaubreview/v6n1s19.pdf

29. Alam, SA, April 22, 2012, Understanding Drug Abuse and Addiction in Bangladesh: A bird's eye view, Available from: http:// profahsanul.blogspot.com/ 2012/04/ understanding-drug-abuse-and-addiction.html

30. Shazzad MN, Abdal SJ, Majumder MSM, Sohel JUA, Ali SMM, Ahmed S, 2013, Drug Addiction in Bangladesh and its Effect, Medicine today, Volume 25 $\mathrm{Nu} \mathrm{m} \mathrm{b} \mathrm{e} \mathrm{r} \quad 02$, Avaialblefrom:http://www.banglajol.info/index.php/ME DTODAY/article/view/17927/12545

31. Salama II, Kotb NK, Hemeda SA, et al. HIV/AIDS knowledge and attitudes among alcohol and drug abusers in Egypt, J Egypt Public Health Assoc. 1998;73(56) : 479-500, Available from : http://www.ncbi.nlm.nih.gov/pubmed/17217020

32. UNICEF, HIV and AIDS in Bangladesh, Available from: http://www.unicef.org/bangladesh/HIV_AIDS(1).pdf 